\title{
Effect of Computerization on Banks' Performance in Quoted Nigerian Banking Sector
}

\author{
Adedeji Elijah Adeyinka \\ Federal University of Technology, Akure \\ Adedokun Taiwo Oyewole \\ Ladoke Akintola University of Technology, Ogbomoso
}

\begin{abstract}
The effect of computerization in banks became of concern to the researcher as its adoption in banking sector and its application has become a major concern to all banks who are deliberating on whether to fully go technological or use partial manual and technology. This study aim to examine the effect of e- banking on ROA of which a survey was carried out on three banks listed on the Nigerian stock Exchange, using panel data of 10 years ranging from 2009 - 2018; while ATM value and volume were used as measurement tool for e-banking, ROA were used as a tool for bank performance. Descriptive analysis was used to ascertain the mean (1.865608; ATM volume, 666288.8; ATM value, 4.514933; ROA) median, Maximum, Minimum. Correlation was carried out and a positive and strong relationship between ATM volume and Value with the performance indicators of selected banks in Nigeria were generated.Regression was carried out on all variables, and hausman test was used to determine which of either pool, random and fixed model to pick, and fixed was picked. Using fixed regression on the effect of e-banking on ROA, the result of the estimated model shows that (ROA) has positive relationship and statistically significant effect on ATM volume in the long run.The work suggests that Management of Nigerian quoted banks should increase their commitments into e- banking channels in order to improve returns from their business transaction.
\end{abstract}

Keywords: Computerization, Technology, E- Banking, Measurement, Performance.

DOI: $10.7176 /$ RJFA/11-16-17

Publication date:August $31^{\text {st }} 2020$

\section{INTRODUCTION}

In this 21 st century, the use of computers in banking system in managing personal and business finances has become more prominent. Indeed, the blending of computer and banking has made the overall management of household and business finances far easier than it ever has been at any point in history, as a result of its blend, it is simple to keep track of various types of financial accounts, all that is needed to do is log onto the computer and quickly access the program for computer and banking.

Computerizations has particularly brought about a paradigm shift in banking operations in Nigeria. In a bid to catch up with global development, improve the quality of customer service delivery, and reduce transaction cost, Nigerian banks currently are investing heavily in computerization, and widely adopting several computerized networks in delivering a wide range of value-added products and services; some of which are Ebanking, information technology etc. The banks' investment in computerization has been corroborated by users' acceptance of the systems despite their concern about network security and security of the system (Adesina,A.A;Ayo,C.K., 2010).Investigation on consumers' acceptance of computerized banking in Nigerian banks based on technology acceptance model (TAM) revealed that banks customers, who are active users of this system use it because it is convenient, easy to use, saves time and meets their transaction needs (Adesina,A.A;Ayo,C.K., 2010).

It is obvious that Nigerian banks have increased speed, shorten processing periods, improve the flexibility of business transactions and reduced costs associated with having personnel serve customers physically; hence agreeing that computerization is paramount. Apparently, with the adoption of computerized banking by all the banks in Nigeria customers now enjoy the new dispensation. In Nigeria, computerization especially in the banking sector, has considerably improved, even though it's not as high when compared to those observed in far advanced countries (Adeyemi, 2006) (Adeoti, 2005)

The impact of computerization in the banking sector became of interest to this study due to the significant role it plays in the economy, though this study majors on electronic banking as one of the means of computerization which has aided efficiency. This aspect of computerization is very vital for any economy that intends to experience meaningful growth because it makes arrangements that bring borrowers and lenders of financial resource together and more efficiently too than if they had to relate directly with one another (Adam, 2002) (Ojo, 2002).In essence, the banking sector acts as a bridge that connects lenders and investors in the economy, hence, computerization aid some form of competitiveness amongst banks especially in customer satisfaction considering the need for reforms in the sector initiated by the Federal Government via the 
instrumentality of the Central Bank of Nigeria-CBN. According to a report by CBN (CBN, 2006), the bank reforms (especially the recapitalization that specifies a minimum capital base of 25 billion naira for commercial banks). In other words, it will change the nature of banks' services in terms of quality which will accumulate in greater customer service delivery and productivity. In addition, E- banking has the ability of improving the competitiveness of Nigerian banking industries making customers the utmost priority and internet technology the bedrock of operation. (Adeoti, 2005) more reason why all banks are venturing into it irrespective of cost.

Performance generally implies whether a bank has fared well within the trading period which is published mainly in the financial statement. Every bank under the sector has set goals and objectives for which is being established but the major of it is expansion and growth, more reason why the essence of computerization cannot be over emphasized in any bank.

\section{Statement of the Problem}

Computerization using the electronic banking is an integral part of any nation that requires speed in redefining its retail bank network and permitting good grounds for effective customer service delivery. The e-banking is the conduct of banking transactions on the platform of information communication technology which drives in immediate and future goals. The absence of the e-banking aspect of computerization in several banks lead to the constant dis-satisfaction by customers who seek elsewhere for better services, hence opening the banks to treat of either a merge or complete dissolution.

The performance of any $21^{\text {st }}$ century bank in the banking industry totally depends on the recently introduced E- banking to attain the sole aim of every retail / commercial bank which is maximization of profit with little or no cost. An important but constantly overlooked challenge facing the banking industry in Nigeria is the problem associated with the tech world; computerization. New computer software's introduced into the system become obsolete less than a year after installation opening the codes that bonds them for hackers to invade making the issue of Data Security a language for persuasion not real.

In Nigerian banks today, the increase in fraud acts has become the order of the day, hackers take information from the data base of banks and use it to threaten certain individual, while others are asked to provide some secrete pins for certain upgrade in the name of the banks. (Rose.P.S., 2001) noted that the advent of computerized banking was mainly for building confidence between banks and customers. The bank is a major part to the economic development of any country, therefore if fraud becomes an issue, trust is lost and inflation sets in causing a slide in the economy of the nation.

Data insecurity either as a result of negligence or by cyber intrusion has caused a great havoc to several customers who end up losing all or part of their savings to cyber theft. According to statistic, from 2002 -2016, the number of customers who have suffered from theft and fraud has increased on a geometric rate due to the absence of the electronic banking system and the non-acceptance by some customers who see it as a means of banks charging more for little or no service rendered. Data insecurity and loss of vital information on customer data base occurred in several banks within the above stipulated year also due to the banks non-inclusion of the newly adopted system in its strategic managerial decision making, the only saw it as a means of customer services and not effective performance.

Consequently, very intense attempts have been put in place by the central bank of Nigeria to curb the issue of data insecurity or fraud in commercial banks today by ensuring the full adoption of the e-banking platforms by all commercial bank in Nigeria by approving the recent bank verification number, aligning our ins used on ATM cards to the national identity cards and some tertiary institutions student's identification cards. This research is aimed at examine those issues that results in the disclosure of data of customers especially in their bid to utilize the electronic banking platform in first bank, first city monument bank and guarantee trust bank.

\section{Research Questions}

1. What effect does e-banking has on ROA in selected banks?

2. What effect does e-banking has on ROE in selected banks?

\section{Research Objectives}

1. Examine the effect of e-banking on ROA of selected banks.

2. Examine the effect of e-banking on ROE of selected banks.

\section{Hypothesis of the Study}

$\mathrm{H}_{0}$ : E-banking has no significant relationship with the performance of first bank, guarantee trust bank, and first city monument bank in the industry.

$\mathrm{H}_{1}$ : E-banking has a significant relationship with the banks performance at first bank, guarantee trust bank and first city monument bank.

\section{LITERATURE REVIEW}

\section{Conceptual Review.}

Computerization marked the beginning of all technological initiatives in the banking industry. Computerization of bank branches had started with installation of simple computers to automate the functioning of branches, 
especially at high traffic branches. Networking of branches are now undertaken to ensure better customer service.

\section{Electronic Banking}

E-banking means a system through which financial service providers, customers, individuals and businesses are able to access their accounts, do transactions and obtain latest information on financial products and services from public or private networks, such as the internet. The term e-banking can be explained in different way from different perspectives. Nonetheless, researchers across the world have made extensive efforts to provide a precise and all-inclusive concept of e-banking.

E-banking is defined as the use of Internet to deliver banking activities, such as transferring funds, paying bills, viewing current and savings account balance, paying mortgages, and purchasing financial instruments and certificates of deposits (Jayshree, 2013) (Uduji, Information technology for effective supervision, 2013)

The term "e-banking" refers to a method of banking through which customers are able to carry out their banking transactions electronically without visiting a bank branch (Simpson 2002). Among other benefits, ebanking saves time, customers need not to visit the bank branch and banks have the opportunity to enhance their customer base thereby experience improved profits (Okibo,B.W;Wario,A.Y, 2014.)

According to Basel Committee Report on Banking Supervision (Supervision., 2014), e-banking is to include the provision of retail and small value banking products and services through electronic channels as well as a large value electronic payment and other wholesale banking services delivered electronically. With respect to the field of banking and financial services, e-banking has been described as a product of e-commerce.

According to Sokolov (2007), financial institutions, in addition to provide traditional banking products and services, can also facilitates a wider array of banking products and services that have been designed or tailored to shore up e-banking. The most common and popular support services are: Electronic card; Phone and mobile bank; Call center; Home bank; Corporate bank and Internet bank.

(Al-Amin,S;Rahman,S. S., 2010) defined that e-banking is such a method through which customers are able to access their accounts and get information about updated products and services provided by banks with the help of a personal computer or other intelligent devices. Existing form of e-banking in Bangladesh takes mainly internet banking, online banking and mobile banking. Among these forms of e-banking, Automated Teller Machines (ATM) and mobile banking are the most popular. Thus, as evident in the above empirical studies, different scholars have conceptualized e-banking from different dimensions. On the basis of literatures explained above, in this paper, we conceptualize e-banking as a method of banking which involves use of information and communication technologies to conduct banking operations.

\section{Types and Delivery Channels of E-banking}

E-banking can be classified into three basic types. These include Internet banking, Smart card banking and Mobile/telephone banking.

Origin of Electronic Banking in Nigeria

Conventional banking system started in Nigeria in 1952. Since then, the industry has witnessed a lot of regulatory and institutional advances. The industry was being controlled by at most five out of the 89 banks in existence before the commencement of the ongoing banking industry reformation in the country. Multiple branch systems is also one of the notable features of Nigerian banks, with a total of 89 banks accounting for about 3017 bank branches nationwide as at 2004. As well, the industry is faced with heavy challenges, including the overbearing impact of fraud and corruption, erosion in public confidence, a poor capital base, persistent cases of distress and failure, poor asset quality, and so on. Part of the moves to resolve these lingering problems include the banking reform initiated by the Central Bank of Nigeria in

June 2004, which is largely targeted at reducing the number of banks in the country and making the emerging banks much stronger and reliable. In the bid to catch up with global developments and improve the quality of their service delivery, Nigerian banks have no doubt invested much on technology; and have widely adopted electronic and telecommunication networks for delivering a wide range of value added products and services. They have in the last few years transformed from manual to automated systems. Unlike before when ledger-cards were used, today banking has been connected to computer networks, thereby facilitating the practice of inter-bank/inter-branch banking transactions. Developments at home, such as the introduction of mobile telephone in 2001 and improved access to personal computers and Internet service facilities have also added to the growth of electronic banking in the country. However, whereas local banks most commonly practice real time online intranet banking, the integration of customers into the process is far from been realized. Many of the reasons are attributed to the high prevalence of Internet fraud and lack of an adequate regulatory framework to protect the banks from the volatility of risks associated with Internet banking, especially at the levels of communication and transaction.

In Nigeria is globally regarded as the headquarters of Advance Fee Fraud which is perpetrated mostly via the Internet. Electronic banking is not one technology, but an attempt to merge several different technologies. Each of these evolved in different ways, but in recent years' different groups and industries have recognized the 
importance of working together. Bankers now see a kind of revolution going on in their business in part because we have taken a quantum leap in the use of technologies in the last several years. According to (Okeci,O.;Oruan,P, 2013) electronic Banking System is an innovative service delivery mode that offers diversified financial services like cash withdrawal, funds transfer, cash deposits, payment of utility and credit card bills, cheque book requests, and other financial enquiries. In Nigeria, ATM was conventionally introduced as an electronic delivery channel in 1989, and was first installed by National Cash Registers (NCR) for the defunct Society General Bank of Nigeria (SGBN) in the same year. Since its introduction, many Nigerian banks have installed ATM in response to the changing nature of modern banking operations. Until 2003, a small number of banks operated their own propriety ATM fleets. The main shared ATM network in Nigeria, Inter Switch, began operations in 2003 with 5 ATMs from United Bank for Africa (UBA) and First Bank of Nigeria (FBN).

\section{Challenges of e-banking in Nigeria}

Commercial banks in Nigeria offer a wide variety of services on the internet. Some of the obvious challenges to an effective banking service delivery in Nigeria include but not limited to the following:

There is no proper infrastructural development for performing e-banking activities in Nigeria.

Slow uptake of internet access and PCS due to high level of illiteracy among Nigerians

There is poor telecommunication network policies and slow paced regulatory initiatives.

There are very few users of internet facilities across the country.

The banking infrastructure in terms of electronic payments and inter-bank connectivity is poor

There is no effective legal system to encourage e-banking activities in Nigeria

There is lack of skilled and efficient IT workforce

Cyber laws to prosecute cybercrimes are not in place

ATMs may have network problems, unavailability and shortage of money as experienced in most ATMs across the country.

\section{Risks in E- Banking}

As we cannot deny the advantages offered through e-banking, same way we cannot ignore the risks involved in e-banking. Bank should maintain adequate leverage between the advantages and risks of e-banking. Although, marketing and advertising campaign initiated by banks are encouraging a number of customers to adapt ebanking, but for managing such a huge customer base banks need to prepare their internal system on prior basis. To have a deep understanding about the risks of e-banking system, it is categorized in various categories, so that bank can effectively design risk management strategies for e-banking. As now e-banking enabled banking beyond the geographical boundaries, banks have local as well as international customers to process their requests or solve their problems. Complexity of e-banking system has increased due to its close network that involves various service delivery mode offered by a bank and open network, such as internet facility that is subject to several risk.

\section{Technology Contentment Theory. (TCT)}

This theory was stated by (Liao,C,Palvia,P,\&Chen,J.L., 2009) as a concept on estimating whether users intend to continue using a technology. The theory blended three renowned models in the domain of technology and IS research: The COG model by Oliver (1980), the TAM by (Davis, 2007), and the ECM by (Bhattacherjee, An empirical analysis of the antecedents of electronic commerce service continuance, 2001). Technology contentment theory was a three-tier model and its ultimate dependent variable was continuance intention with IS. TCT blended two essential constructs: Contentment and attitude, as well as three first-tier precursors: Validation, perceived user-friendliness, and PU. The Technology contentment theory encompassed all the hypotheses put forth in ECM and TAM, (Liao, 2009). Researchers have put in hard work for over a decade to formulate hypothetical models, which encompass ECM and TAM to define and predict the espousal and continuance conduct of users in terms of IS. Conceived for the research on continuance behavior, the COG model is a mix of different variables from ECM and TAM. The Technology contentment theory can be deployed at different stages of usage: Preliminary, short-term and long-term. Technology contentment theory is a significantly improved model in comparison to ECM and TAM, with respect to the breadth of applicability and descriptive strength (Liao, 2009). Liao (2009) explored the creation of an enhanced model for continuance with respect to IS, which can be harnessed all through the usage stages. To start with, an analysis of the ECM and TAM, models was carried out. These models vary in their opinions on the essential notions that affect user conduct.

\section{Empirical Review.}

(Hernando,I.;Nieto,M.J., 2006), using a sample of 72 Spanish commercial banks and data over a period of 1994 2002, found that impact of adoption of e-banking system takes time to contribute to performance of banks and for the sample banks authors found significant positive impact, after three years of adoption of e-banking system, of a transactional web site on financial profitability, measured in terms of Return on Equity (ROE) and Return on Assets (ROA), of the banks. (Aduda,J;Kingoo,N., 2012). Established a positive relationship between e-banking and financial performance of banks by using Pearson Product-Moment Correlation Coefficient test. Using data 
of twenty-seven banks over the period of 2006 to 2010, authors found that e-banking has strong and significant marginal effects on returns on asset in the banks operating in Kenya.

(Onay,C.; Ozsoz,E., 2013). Used panel data over the period of 1990-2008 of eighteen retail banks operating in Turkey and revealed that Internet banking adoption is positively associated with the level of profits, deposits and loans per branch. Their study also revealed that adoption of internet banking has a negative impact on bank profitability after 2 years of adoption. According to the authors, the reasons for such negative impact is internet banking increases competition and results in lower interest income. (Al-Smadi, M. O.; Al-Wabel, S. A, 2011). Studied the impact of e-banking as a form of computerization on the performance of Jordanian banks using a panel data of fifteen Jordanian banks for the period of 2000-2010. Using pooled OLS regression technique they found significant negative impact of e-banking on performance of banks. The major limitation of this study is that authors did not look at ROE after a specific year of adoption of e-banking. Since adoption of e-banking technology involves cost, this might take time to recover cost and experience profits.

On the other hand, in Indian context (Malhotra, P.; Singh, B., 2009) studied the effects of electronic banking on performance of Indian commercial banks and found no significant relationship between the profitability performance and the adoption of the internet/ electronic banking. It could be seen from the above explained empirical literatures that the impact of Electronic banking as a means of the computerization on banks' performance that it provides mixed evidences and thus inconclusive.

Therefore, it brings an open ground for the academicians, researchers, regulators and supervisors to know empirically the impact of e-banking as a means of computerization on the performance of banks

\section{Research Design}

Descriptive analysis was used to describe relevant aspects of banks performance and provides detailed information about each relevant variable. Correlation models, specifically Pearson correlation was used to measure the degree of association between different variables under consideration while regression analysis was used to examine the relationship of independent variables with dependent variable and to know the effect of selected independent variables on banks performance. The researcher also used Ordinary Least Squares (OLS) method for analysis of hypotheses stated in a multiple form. For this purpose of analysis, the E-View was use to analyses financial data and to run the regression.

\section{Study Area}

The study area of the research work was selected banks listed on the Nigerian Stock Exchange (NSE). The banks include; Access bank, Eco- bank, Fidelity bank, First bank, Heritage bank, Key bank, Polaris bank, providus bank, Stabic Ibtc bank, Standard chartered bank, Sterling bank, Union bank plc, United bank for Africa, Wema bank, Zenith bank plc, First city monument bank, Guaranty trust bank.

\section{Source of data}

These research work used only secondary data obtained from the audited annual reports and financial statements of the selected banks for a period of ten (10) years. for the period 2009- 2018. These financial statements contain balance sheet, profit \& loss account, cash-flow statement, notes to financial statements and profile of the firms among others.

\section{Data collection Measurement of Variables.}

This subsection presents the computerization (e-banking) and banks performance variable of this study that was adopted together with its measurement. They are divided into two major parts, the dependent and independent variable. The Dependent variable which is the banks performance, while the Independent variable is computerization. Furthermore, the dependent variable was proxy with return on Asset (ROA), and return while the independent variable will be proxy to ATM value for these banks and the ATM volume.

\section{Method of Data Analysis}

This work analyzed the level of performance recorded by the banks of study using the E-banking using the model below;

The regression model is given thus;

$\mathrm{Y}=f(\mathrm{X})$.

This means $\mathrm{y}$ is a function of $\mathrm{x}$. i.e. $\mathrm{y}$ is dependent on $\mathrm{X}$

$\mathrm{Y}$ is a dependent variable (Banks' Performance measured by Return on assets and Return on equity of banks in view).

$\mathrm{X}$ is an independent variable (Electronic Banking)

$\mathrm{X}_{1}=\mathrm{ATM}$ Volume

$\mathrm{X}_{2}=\mathrm{ATM}$ Value $/$ Total cash dispensed.

$\mathbf{Y}_{\text {it }}=\boldsymbol{\beta}_{\mathbf{0}}+\beta_{1} \mathbf{X}_{1}+\beta_{2} \mathbf{X}_{\mathbf{2}}+\boldsymbol{\varepsilon}_{\mathrm{it}}$

Basically, in line with the two last objectives of the study, an aspect measure of E-banking will be use; ATM Volume and Value and two measures for performance will be use; ROA, ROE which gives us a broad model;

$\mathbf{( R O A}_{i t}=\alpha_{0}+\beta_{1}(\mathrm{ATMV})_{\text {it }}+\beta_{2}\left(\mathrm{ATMV}_{\mathrm{L}}\right)_{\text {it }}+\varepsilon_{i t}$

where; 
Yit : Represent banks' performance represented by ROA of bank. $\alpha_{0}$ : means the Constant factor

$\beta_{1}(\mathrm{ATMV})$ it : the volume of ATM amongst the selected banks

E- error term

\section{RESULT AND DISCUSSIONS \\ Descriptive Statistics}

This study carried out the following descriptive statistics; mean, variance, standard deviation, minimum and maximum values, normality test using skewness and kurtosis and the results are reported in Table 4.1 The tables show that the mean ROA of the three selected banks is 4.514933 with minimum and maximum value of $12.61471,11.51850$ respectively. This means the average performance in financial terms for the banks is summed as $452.1 \%$. The study also finds that the average value of ROE is $128.1 \%$ with the minimum and maximum value of $-40.45181,45.31576$ respectively. For skewness ROA are negatively skewed. The kurtosis shows that ROA of $(5.931508,5.136772)$ respectively are leptokurtic because they are above 3 , which means the investment return is risky for investors because there is an every probability that the investment would experience extreme return 0r a loss.

The descriptive statistics for the independent variables indicates that banks under this study have a mean of $67.28 \%$ for its ATM Volume, and also have a mean value of $18.67 \%$ for its ATM value thus indicating that averagely the ATM value/ transaction is lower compared to ATM Volume/ number of usage. For skewers both independent variables positively skewed. Both the independent variable is leptokurtic because they are above 3 .

Table 4.1: Descriptive Analysis of dependent and independent variable

\begin{tabular}{|l|l|l|l|l|}
\hline & ATM VOLUME & ATM VALUE & ROA & ROE \\
\hline Mean & 1.865608 & 666288.8 & 4.514933 & 12.76023 \\
\hline Median & 1.714208 & 295476.0 & 4.888615 & 13.72232 \\
\hline Maximum & 6.483408 & 8755190 & 11.51850 & 45.31576 \\
\hline Minimum & 17309465 & 114760.0 & -12.61471 & -40.45181 \\
\hline Std. Deviation & 1.487608 & 1548648 & 4.987077 & 17.09856 \\
\hline Kurtosis & 4.690303 & 26.55575 & 5.931508 & 5.136772 \\
\hline Skewness & 1.333923 & 4.981467 & -1.335008 & -1.040295 \\
\hline Jarque- Bera & 12.46815 & 8176667 & 19.65341 & 11.11831 \\
\hline Probability & 0.001961 & 0.000000 & 0.000054 & 0.003852 \\
\hline Sum & 5.5807609 & 199988665 & 135.4480 & 382.8070 \\
\hline $\begin{array}{l}\text { Sum } \\
\text { Deviation }\end{array}$ & 6.9667113 & 721.2573 & 382.8070 \\
\hline Observation & 6.3856009 & 30 & 30 & 30 \\
\hline \multicolumn{2}{|l|}{} & & & \\
\hline
\end{tabular}

Source: Researcher's computations, 2019

Correlation Analysis

The result of the correlation exercise for e-banking is presented in table 4.2, where the values show the correlation coefficient of the variables. As shown in the table, ATM volume, ATM value represents sub-index of financial while the performance indicators include return on asset (ROA), and return on equity (ROE).

Outputs of the two sub-index of e-banking positively correlated with returns on asset (ROA). However, such association is very strong, conversely, the correlations between ATM volume and ROE is weak (0.045386461) compared to ATM value and ROE (0.349237474) due to the difference of the variables. The table shows a positive but strong relationship between ATM volume and Value with the performance indicators of selected banks in Nigeria. 
Table 4.2: Correlation Analysis

\begin{tabular}{lrrrrr}
\hline & \multicolumn{1}{c}{ ROA } & ROE & & ATM VOLUME & ATM VALUE \\
\hline ROA & 1 & & & & \\
ROE & 0.93302046 & 1 & 1 & & \\
ATM VOLUME & 0.237484597 & 0.045386461 & & 1 & 1 \\
ATM VALUE & 0.400874835 & 0.349237474 & & -0.03799124 & 1 \\
\hline$* * * p<0.01 * * p<0.05$ & & & & &
\end{tabular}

Source: Research findings

Regression Analysis

This study employed cross sectional panel data, it uses pooled ordinary least squares (OLS), fixed effect and random effect model to estimate the coefficient of the independent variables. The study used hausman test to check the appropriate model between random effect and fixed effect model for the analysis. If the probability test is lower than 0.05 then random effect model is appropriate or otherwise.

\section{Effect of E- Banking on ROA}

Table 4.3 indicates the regression results of the panel data using pooled, fixed and random effects model for equation 1 where ROA is the dependent variable. Since the hausman test is higher than 0.05 , we choose the fixed effect model. The result of the estimated model shows that (ROA) has positive relationship and statistically significant effect on ATM volume in the long run since sig value. This indicates that an increase in the volume of the ATM transaction being a channel of the electronic banking will lead to $484 \%$ increase in return on asset. In other words, banks increased in performance measured by total assets because they engaged more of the ebanking channels to its operations. The coefficient of ATM volume/ number of transactions to equity ratio shows that it has a positive impact on banks performance in Nigeria. This implies that a $1 \%$ increase in ATM value/ cash dispense ratio will positively lead to $60 \%$ increase in the performance of banks. The coefficient of determination $\left(\mathrm{R}^{2}\right)$ and its adjusted $\mathrm{R}^{2}$ are 0.712224 and 0.086180 respectively implying that there exists goodness of fit in the model. This means that about $80 \%$ of the variation in ROA is accounted for by variation in ATM volume of transactions and the value of the transactions, the remaining $20 \%$ is unexplained variable is largely due to variation in other variables outside the regression model which are otherwise included in the stochastic error term. According to DW statistics of (1.782382) there is negative autocorrelation in the models which means the residual is not normally distributed.

\begin{tabular}{|c|c|c|c|c|}
\hline VARIABLE & & POOLED(OLS) & RANDOM(RE) & FIXED(FE) \\
\hline \multirow[t]{2}{*}{ 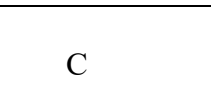 } & Value & 4.47875 & 4.47875 & 4.47875 \\
\hline & Coefficient & 0 & -0.0007 & -0.0008 \\
\hline \multirow{2}{*}{ ATM Volume } & Value & 4.84307 & 4.84307 & 4.84307 \\
\hline & Coefficient & 0 & 0.0208 & 0.0214 \\
\hline \multirow[t]{2}{*}{ ATM value } & Value & 5.59809 & 5.59809 & 5.59809 \\
\hline & Coefficient & 0.0091 & 0.0667 & 0.0675 \\
\hline R-squared & Coefficient & 0.87603 & 0.71222 & 0.71222 \\
\hline $\begin{array}{l}\text { Adjusted R- } \\
\text { squared }\end{array}$ & Coefficient & 0.11866 & 0.15387 & 0.08618 \\
\hline $\begin{array}{l}\text { Durbin-Watson } \\
\text { stat }\end{array}$ & Coefficient & 1.76674 & 1.78238 & 1.78238 \\
\hline (F-statistic) & Coefficient & 17.0886 & 3.63685 & 1.68373 \\
\hline \multicolumn{2}{|l|}{ HAUSMAN } & & & \\
\hline TEST & & 1 & 1 & 1 \\
\hline
\end{tabular}

* Significant at $10 \%$ Level

Source: Statement of Financial Position 


\section{Effect of E- Banking on ROE}

Table 4.4. shows that (ROE) has a negative relationship and statistically insignificant effect on ATM volume/ number of usage. This indicates that an increase in ATM's volume of dispense, will lead to decrease in performance of banks based on its market value of $14 \%$ in the long run. This is an indication that for big banks in the first generation bank won't necessarily have returns on the investments of shareholders with the number of ATM usage as most ATM users might not withdraw and also considering the CBN policy of \#65 from the third withdrawal in a month. Hence, there is no significant relationship between these two variables. The coefficient of ATM value ratio also shows negative and an insignificant relationship with ROE. This implies that a $1 \%$ increase in ATM value ratio will not lead to an increase in performance of bank in the long run.

The coefficient of determination $\left(\mathrm{R}^{2}\right)$ and its adjusted $\mathrm{R}^{2}$ are 0.726033 and 0.613802 respectively implying that there exists goodness of fit in the model. This means that about $72 \%$ of the variation in ROE is accounted for by variation in ATM number/ volume and ATM value respectively. And the remaining $28 \%$ is unexplained variable is largely due to variation in other variables outside the regression model which are otherwise included in the stochastic error term. The overall regression (F-Test) is 0.901296. According to DW statistics of (1.715212) there is negative autocorrelation in the models which means the residual is not normally distributed.

Table 4.4 Regression Statistics on the effect of E-Banking on ROE

\begin{tabular}{llll} 
VARIABLE & POOLED( OLS) & RANDOM(RE) & FIXED(FE) \\
\hline C & 25.34214 & 25.34214 & 25.34214 \\
ATM VOLUME & $(0.0000)$ & $(0.0000)$ & $(0.0000)$ \\
& -1.420006 & -1.423106 & -1.423106 \\
ATM VALUE & 0.0000 & 0.0685 & 0.0693 \\
& -9.500009 & -9.500409 & -9.500409 \\
R-SQUARE & 0.0091 & 0.4003 & 0.4009 \\
ADJUSTED R- SQUARE & & & 0.726033 \\
F- STATISTIC & 0.726033 & 0.726033 & 0.613802 \\
DUBIN WATSAON STAT & 0.613802 & 0.613802 & 0.901296 \\
HAUSMAN & 0.901296 & 1.946800 & 1.715212 \\
\hline
\end{tabular}

\section{CONCLUSION AND RECOMMENDATIONS}

Overall, the findings on the selected banks for ten years provide evidence that computerization has effect on different areas of banking performance. The result showed that ATM value and volume has a positive and significantly affects R0A, while ATM volume has a negative and significant effect on ROE as compared to the positive relationship of ATM value on ROE. From the research findings we can conclude that E-banking is vital for any profit maximizing bank and the negative relationship of ATM volume to ROE is a wakeup call for the management and board of directors of these Banks to invest more on e- banking channels like ATM for more number of transactions to be carried out as the more the transactions the more charges are deducted and card maintenance fee removed which will eventually accrue to the banks' as income.

In accordance with the findings of this study, which revealed that e-banking has significant effect on the performance of Nigerian banking sector and the conclusion drawn by the study, the following recommendation are made:

1 The Management of Nigerian quoted banks should increase their commitments into e- banking channels in order to improve returns from their business transaction.

2. Investors and stakeholders of quoted banks in Nigeria should also consider the financial stability level of any bank before committing their hard earned money as the strength of a bank financing mix determine the quantum of their returns.

\section{REFERENCE}

Adam, A. (2002). Financial Intermediation and Economic Growth: Evidence from Nigeria. Journal of Economic Management, 5(2), 25-48.

Adeoti, J. (2005). "Information Technology Investment in Nigerian Manufacturing Industry. 2005 Annual Conference, Ibadan Nigerian Economic, (pp. 213-244). Ibadan.

Adesina A,A;Ayo,C.K. (2001). An Empirical Investigation of the Level of Users' Acceptance of e-banking in nigeria. Journal of Internet Banking and Commerce, 15, 1.

Adesina,A.A;Ayo,C.K. (2010). An Empirical Investigation of the Level of Users' Acceptance of Ebanking in Nigeria. Journal of Internet Banking and Commerce, 15, 1.

Adesola,M.A,Moredeyo,O.A, \& Oyeniyi,K.O. (2013). Impact of information communication technology on 
Nigerian banks operations. International Journal of Business and Management Innovation, 2(9), 07-12.

Adeyemi, K. (2006). Banking Sector Consolidation in Nigeria: Issues and Challenges. Union Digest, 9, 3-4.

Aduda,J;Kingoo,N. (2012). The relationship between electronic banking and financial performance among commercial banks. Journal of Finance and Investment Analysis, 1(3), 99-118.

Agboola, A. (2002). Information Technology, Bank Automation, and Attitude of Workers in Nigerian Banks. Journal of Social Sciences.

Ajzen, I. (1991). Organizational Behavior and human decision process. The theory of planned behavior., 50(2), 179-211.

Al-Amin,S;Rahman,S. S. (2010). Application of electronic banking in Bangladesh. Bangladesh Research Publications Journal, 4(2), 172-184.

Almajali,Y.A,Alamro,A.S.\&Al-Soub,Z.Y. (2012). Factors Affecting the Financial Performance of Jordanian Insurance Companies Listed at Amman Stock Exchange. Journal of Management Research, 4(2), 226-289.

Al-Smadi, M. O.; Al-Wabel, S. A. (2011). The impact of e-banking on the performance of Jordan banks. Journal of Internet Banking and Commerce, 16(2), 1-10.

Bhattacherjee, A. (2001). An empirical analysis of the antecedents of electronic commerce service continuance. Decision support systems, 32(2), 201-14.

Bhattacherjee, A. (2001). Understanding information systems continuance. MIS Quarterly, 25(3), 351-370.

Booz. (2002). E-banking and banking sector. kano: bayaro university.

Brücher,H;Scherngell,L. (2008). Change management in e-government. Fachzeits chrift desCC e-Gov der Berner, 11-1.

CBN. (2006, January 3). Press Release. 9902, 22, p. 11

Davis, F. (2007). Perceived usefulness, perceived ease of use, and user acceptance of information technology. MIS Quarterly, 13(3), 319-340.

Hernando,I.;Nieto,M.J. (2006). Is the internet delivery Channel Changing? The Case of Spanish Banks" Banco de Espana Working Paper.

Ho, C. (2010). Continuance intention of e-learning platform. International Journal of Electronic Business Management, 8(3), 206-213.

Iswatia,S; Anshoria,M. (2007). The Influence of Intellectual Capital to Financial Performance at Insurance Companies . Proceedings of the 13th Asia Pacific Management Conference. Melbourne: Jakarta Stock Exchange (JSE).

J.Ovia. (2001). Financing Information and Communication Technology. Lagos.

Jayshree, C. (2013). Internet banking: Benefits and challenges in an emerging economy. International Journal in Research and Business Management, 1(1), 19-26.

Karimzadeh,D.S.D.;Emadzadeh,D.M.;Shateri,J. (2014). The effects of electronic banking expansion on proftability of a commercial bank. Journal of Scientifc Research, 4(6), 305-312.

Leow, H. (2003). New Distribution Channels in banking Services. Banker's Journal Malaysia, 48-56.

Liao,C,Palvia,P,\&Chen,J.L. (2009). Information technology adoption behavior life cycle. International Journal of Information Management, 29(4), 309-320.

Malhotra, P.; Singh, B. (2009). The impact of internet banking on bank performance and risk. Eurasian Journal of Business and Economics, 2(4), 43-62.

Nikolai L;Bazlay J.D. (1997). Corporate accounting for finance. Intermediate Accounting, 7(9), 3-8.

Nikolai L;Bazlay J.D. (1997). Intermediate Accounting. Ohio: South-Western College Publishing.

Ojo, J. (2002). Financial Sector Maladaptation, Resource Curse and Nigeria's Development Dilemma. Public Lecture. Ota, Ogun State: Covenant University.

Okeci, O.;Oruan, P. (2013). Empirical Evaluation of Customers' Use of Electronic Banking Systems in Nigeria. African Journal of Computing \& ICT, 6(1).

Okeci,O.;Oruan,P. (2013). Empirical Evaluation of customers' use of E-banking in Nigeria. African Journal of Computing \& ICT, 6(1).

Okibo,B.W;Wario,A.Y. (2014.). Effects of e-banking on growth of customer base in Kenyan banks. International Journal of Research in Management \& Business Studies, 1(1), 78-84.

Oliver, R. (2005). A cognitive model of the antecedents and consequences of satisfaction decisions. Journal of Marketing Research, 17(4), 460-469.

Onay,C.; Ozsoz,E. (2013). The impact of internet-banking on brick and mortar branches. Journal of Financial Services Research, 44(2), 187-204.

Ongore,V.O;Kusa,G.B. (2013). Determinants o fFinancial Performance of Commercial Banks . International Journal of Economics and Financial Issues, 3(1), 1.

Osinupebi, F. (2010). The Nigerian bank consolidation of 2005. The Heinz Journal, 9(2), 1-10.

Ovia. (2005). Enhancing the Efficiency of the Payment System in Nigeria. CBN Bullion, 29, 8-18.

Ovia, J. (2005). Enhancing the Efficiency of the Payment System in Nigeria. CBN Bullion, 29(1), 8-18. 
Oyewole,O.S,Abba,M.,El-Maude,\&Gambo,J. (2013). E-banking and bank performance. International Journal of Scientific Engineering and Technology, 2(8), 766-771.

Rauf,S.;Qiang,F. (2014). The integrated model to measure the impact of e-banking on commercial banks. Journal of Research in Banking and finance, 4(1), 25-45.

Rose.P.S. (2001). Commercial Bank Management (5 ed.). McGraw-Hill Irwin.

Sanusi, L. (2010). The Nigerian banking industry: What went wrong and the way forward. Convocation lecture. kano: bayaro university,kano.

Shoewu,O;Edeko,F.O. (2011). Outgoing call quality evaluation of GSM network services. American journal of scientific and industrial research, 1-5.

Simpson, J. (2002). The impact of the internet in banking. Telematics and Informatics, 19(4), 315-330.

Soludo, C. (2004). Consolidating the Nigerian banking industry to meet the development challenges of the 21stcentury. Abuja: Bankers' Committee-CBN.

Supervision., B. C. (2014). Risk management principles for electronic banking. Bank for International Settlements, 4-8.

Uduji, J. (2013). Information technology for effective supervision. Journal of Economic and Sustainable Development, 4(9), 82-90.

Uduji, J. (2013). Public relations for improving public perception of the marketing executives in the banking industry in Nigeria. Journal of Economics and Sustainable Development, 4(8), 76-83.

Woherem, E. (2000). Information Technology in the Nigerian Banking Industry. Ibadan: Spectrum. 